\title{
"Crisis, Conspiracy, and Community in Evangelical Climate Denial",
}

\section{Aaron Ricker, Independent Scholar}

\begin{abstract}
Statistically speaking, American Evangelical Christians are uniquely attracted to apocalyptic conspiracy theories when it comes to the topic of climate change. Since Evangelicals constitute a powerful voting/lobbying/shopping bloc, it is worth asking why this might be the case and what (if anything) can be done about it. To this end, my study considers the relevance of two major cultural tributaries to American Evangelical pop apocalyptic culture. In the first section I consider biblical apocalyptic culture and argue that the characteristic apocalyptic promise to disclose hidden divine plans to a misunderstood but soon-tobe-vindicated elect group naturally entails conspiracy-theory thinking. I argue further that apocalyptic imagination and conspiracy-theory thinking are powerful tools for the definition of identity and community. In the second section I turn my attention to the kind of Evangelical pop apocalyptic culture that helped push climate science denial into the Christian mainstream. I argue that in pop apocalyptic productions like the influential tracts and comics of Jack T. Chick, the image of the elect as the persecuted and powerful bearers of special knowledge found a new lease on life, and continues to fascinate millions with the attractive offer of somebody special to be and somewhere special to belong. I conclude that apocalyptic questions of crisis and conspiracy have a sociological function, as means to the end of defining social identity. Understanding this concrete function of conspiracy-theory thinking in Christian apocalyptic imagination can help in assessing and addressing the troubling phenomenon of Evangelical climate denial.
\end{abstract}

Keywords: Conspiracy Theories; Apocalypticism; Evangelicalism; Climate Denial; Social Identity.

$\mathrm{T}$ The president of the United States has repeatedly called climate change a "hoax" perpetrated by false "prophets of doom." ${ }^{3}$ This is an extraordinary level of mainstream success for an unadorned conspiracy theory. I argue here that the political mainstreaming of conspiracy-minded climate denial has been supported, somewhat paradoxically, by religious sectarianism. Climate denial is not only politically convenient, that is, because it is business-friendly and status-quo-friendly. It is also conveniently Evangelical-friendly. Statistically speaking, Evangelical Christians support the Trump presidency far and away more dependably than their neighbours do. ${ }^{4}$ They are also about twice as likely to dismiss climate change as a hoax. ${ }^{5}$ The reasons they cite for the latter opinion tend toward the eschatological. Many insist that God's semi-discernible plan for the end of the world is unfolding as it should, making human climate

1. Biblical references are from The Holy Bible: New Revised Standard Version (Nashville: Thompson Publishers, 1989).

2. Jeremy Schulman, "Every Insane Thing Donald Trump Has Said About Global Warming," Mother Jones, December 12, 2018, https://www.motherjones.com/environment/2016/12/trump-climate-timeline/.

3. Helier Cheung, "What Does Trump Actually Believe on Climate Change?" BBC News, January $23,2020$. https://www.bbc.com/news/world-us-canada-51213003.

4. Philip Schwadel and Gregory A. Smith, "Evangelical Approval of Trump Remains High, But Other Religious Groups are Less Supportive," Pew Research Center, March 18, 2019, https://www.pewresearch.org/fact-tank/2019/03/18/evangelicalapproval-of-trump-remains-high-but-other-religious-groups-are-less-supportive/; Jessica Martinez and Gregory A. Smith, "How the Faithful Voted: A Preliminary 2016 Analysis," Pew Research Center, November 9, 2016, https://www. pewresearch.org/fact-tank/2016/11/09/how-the-faithful-voted-a-preliminary -2016-analysis/.

5. Robin Globus Veldman, The Gospel of Climate Skepticism: Why Evangelical Christians Oppose Action on Climate Chan- 
decisions irrelevant to the fate of the planet. ${ }^{6}$ From this point of view, science-based alarm about the climate looks suspiciously like a liberal/scientistic "attack" on faith. ${ }^{7}$ From a point further down the same path of conspiracy-theory thinking, some Evangelicals warn that global climate initiatives could amount to an apocalyptic trap set by Satan. Supranational agreements on emergency climate action could create a legislative Trojan Horse for the one-world government of the Antichrist. ${ }^{8}$ Many hedge their bets by adding that catastrophic global warming might be secretly a good thing - a new stage in God's end-time plan to burn our sinful world away. ${ }^{9}$

Although American Evangelical opinion on these matters is not monolithic (many American Evangelicals are willing to acknowledge and act on climate change), ${ }^{10}$ the marriage of apocalyptic imagination and conspiracy-theory thinking just described constitutes a strange and dangerous kind of normalcy. Since Evangelicals make up something like a quarter of the US population, and constitute a powerful voting/lobbying/shopping bloc, ${ }^{11}$ it is well worth asking why so many otherwise mainstream North Americans prefer apocalyptic conspiracy theories when it comes to discussing climate change, and what (if anything) can be done about it. To this end, my study considers the relevance of two major cultural tributaries to American Evangelical pop apocalyptic culture. In the first section I consider biblical apocalyptic culture, and argue that the characteristic apocalyptic promise to disclose hidden divine plans to a misunderstood but soon-to-be-vindicated elect group naturally entails conspiracy-theory thinking. I argue further that apocalyptic imagination and conspiracy-theory thinking are powerful tools for the definition of

ge (Oakland, CA: University of California Press, 2019), 1-3; Cary Funk and Becka A. Alper, "Religion and Views on Climate and Energy Issues," Pew Research Center, October 22, 2015, 32-37, https://www.pewresearch.org/internet/wpcontent/uploads/sites/9/2015/10/PI_2015-10-22_religion-and-science_FINAL.pdf; Robert P. Jones, Daniel Cox, and Juhem Navarro-Rivera, Believers, Sympathizers and Skeptics: Why Americans are Conflicted about Climate Change, Environmental Policy, and Science. Findings from the PRRI/AAR Religion, Values, and Climate Change Survey (Washington, DC: Public Religion Research Institute, 2014), 2-3.

6. Dawn Stover, "Evangelicals for Climate Action," Bulletin of the Atomic Scientists 75, no. 2 (2019): 70; Lisa Vox, "Why Don't Christian Conservatives Worry about Climate Change? God," Washington Post, June 2, 2017,

https://www.washingtonpost.com/posteverything/wp/2017/06/02/why-dont-christian-conservatives-worry-about-climatechange-god/; Bernard Daley Zaleha and Andrew Szasz, "Why Conservative Christians Don't Believe in Climate Change," Bulletin of the Atomic Scientists 71, no. 5 (2015): 19-30.

7. Veldman, The Gospel of Climate Skepticism, 107-108; Wylie Carr, Michael Patterson, Laurie Yung, and Daniel Spencer, "The Faithful Skeptics: Evangelical Religious Beliefs and Perceptions of Climate Change," Journal for the Study of Religion, Nature and Culture 6, no. 3 (2012): 289.

8. Carr et al, "The Faithful Skeptics," 292-293; Jillian Cheney, "Why Many Evangelicals Believe Climate Change Is A Hoax," Religion Unplugged, September 27, 2019, https://religionunplugged.com/news/2019/9/27/climate-change-andevangelicals-why-do-so-many-of-them-believe-its-a-hoax.

9. Veldman, The Gospel of Climate Skepticism, 69, 72-75, 82-85; Connie Roser-Renouf, Edward Maibach, Anthony Leiserowitz and Seth Rosenthal, "Global Warming, God and the 'End Times," Yale Program on Climate Change Communication, July 26, 2016; Jones et al., "Believers, Sympathizers, and Skeptics," 4, 23-24; David C. Barker and David H. Bearce, "End-Times Theology, the Shadow of the Future, and Public Resistance to Addressing Global Climate Change," Political Research Quarterly 66, no. 2 (2013): 269; Carr et al., "The Faithful Skeptics," 293; Barbara Rossing, "Hastening the Day When the Earth Will Burn: Global Warming, 2 Peter, and the Book of Revelation," in The Bible in the Public Square: Reading the Signs of the Times, ed. Cynthia Briggs Kittredge, Ellen Bradshaw Aitken and Jonathan A. Draper (Minneapolis: Fortress, 2008), 25-38.

10. See for example Stover, "Evangelicals for Climate Action"; Laurel Kearns, "Green Evangelicals," in The New Evangelical Social Engagement, ed. B. Steensland and P. Goff (Oxford: Oxford University Press, 2014), 157-178; Katharine K. Wilkinson, Between God and Green: How Evangelicals Are Cultivating a Middle Ground on Climate Change (Oxford: Oxford University Press, 2012).

11. See Frances Fitzgerald, The Evangelicals. The Struggle to Shape America (Toronto: Simon and Schuster, 2017); “America's Changing Religious Landscape,” Pew Research Center May 12, 2015, https://www.pewforum.org/2015 105/12/americas-changing-religious-landscape/; Brian McCammack, "Hot Damned America: Evangelicalism and the Climate Change Policy Debate," American Quarterly 59, no. 3 (2007): 645-668. 
identity and community. In the second section I turn my attention to the kind of Evangelical pop apocalyptic culture that helped push climate science denial into the Evangelical Christian mainstream. I argue that in pop apocalyptic productions like the influential tracts and comics of Jack T. Chick, the image of the elect as the persecuted and powerful bearers of special knowledge found a new lease on life, and continues to fascinate millions with the attractive offer of somebody special to be and somewhere special to belong. I conclude that apocalyptic questions of crisis and conspiracy have a sociological function, as means to the end of defining social identity. There are naturally other factors at work in Evangelical climate denial that need continued scholarly attention (from traditions deemed "theological" to dynamics deemed "political"), ${ }^{12}$ but understanding the function of conspiracy-theory thinking in Christian apocalyptic imagination can help in assessing and addressing the troubling phenomenon.

\subsection{Crisis, Conspiracy, and Community in Biblical Apocalyptic}

The label "apocalyptic" is used to describe a variety of things, and can therefore create confusion and controversy. ${ }^{13}$ For our purposes here, it is enough to note that an apocalypse is literally a "revelation" ( $\dot{\alpha} \pi \circ \kappa \alpha \dot{\lambda} v \psi 1 \varsigma$ ), and that cultural products called "apocalyptic" typically purport to reveal the secret inner workings of the world - usually with reference to visions of its last days. ${ }^{14}$ This eschatological expression of apocalyptic imagination is particularly dependable and pertinent in the case of biblical apocalyptic literature and derivative traditions. ${ }^{15}$ Biblical apocalyptic traditions are crucially relevant to understanding conspiracy-minded Evangelical apocalyptic imagination because they enjoy such a privileged place in American Evangelical culture, ${ }^{16}$ and because they tie Christian apocalyptic thinking at the root to questions of crisis, conspiracy, and community.

\subsection{Crisis}

Apocalyptic literature has often been called "a literature of crisis," because the work of "revelation" offered in the text of an Apocalypse commonly includes a vision of the proper way for a given community to understand and endure a given crisis. ${ }^{17}$ The picture is complicated by the fact that such diagnoses are

12. See, for example, Antony Alumkal, Paranoid Science: The Christian Right's War on Reality (New York: New York University Press, 2018), 153-192; Laurel Kearns, "Cooking the Truth: Faith, Science, the Market and Global Warming," in Ecospirit: Religions and Philosophies for the Earth, ed. L. Kearns and C. Keller (New York: Fordham University Press, 2007), 97-124.

13. John J. Collins, "What is Apocalyptic Literature?” in The Oxford Handbook of Apocalyptic Literature, ed. J. J. Collins, (Toronto: Oxford University Press, 2014), 1-18; Lorenzo DiTomasso, “Apocalypticism and Popular Culture," in The Oxford Handbook of Apocalyptic Literature, ed. J. J. Collins (Toronto: Oxford University Press, 2014), 473-509.

14. Collins, "What is Apocalyptic Literature?," 2; James H. Charlesworth, "Introduction," in The Old Testament Pseudepigrapha Vol. 1: Apocalyptic Literature and Testaments, ed. J. H. Charlesworth (Peabody, MA: Hendrickson, 1983), 3; Madeleine Scopello, "The Revelation of Adam," in The Nag Hammadi Scriptures, ed. Marvin Meyer (San Francisco: HarperOne, 2007), 343-345.

15. See Frederick J. Murphy, Apocalypticism in the Bible and Its World: A Comprehensive Introduction (Grand Rapids, MI: Baker Academic, 2012), 10; Jerry L. Walls, "Introduction," in The Oxford Handbook of Eschatology, ed. J. L. Walls (Toronto: Oxford University Press, 2008), 12-15; John J. Collins, "Apocalyptic Eschatology in the Ancient World," in The Oxford Handbook of Eschatology, ed. J. L. Walls (Toronto: Oxford University Press, 2012), 46-47.

16. Matthew Avery Sutton, American Apocalypse: A History of Modern Evangelicalism (Cambridge, MA: Belknap / Harvard University Press, 2014), 326-365.

17. See, for example, Craig R. Koester, Revelation: A New Translation with Introduction and Commentary (New Haven: Yale University Press, 2014), 132-136; Leonard L. Thompson, The Book of Revelation: Apocalypse and Empire (New York: Oxford University Press, 1990), 25-27. 
perspectival. Almost any situation could conceivably be classified as a crisis by one observer or another. ${ }^{18}$ A book like Revelation may in fact be written at times for the benefit of relatively comfortable people, to convince them that the status quo is actually doomed and evil, and to portray success in mainstream society as a damnable moral failure. ${ }^{19}$ It may be written, in other words, "to create a crisis - not to respond to one." 20 In such cases, the apocalyptic vision thus articulated is a krisis in its own right, in the original Greek sense

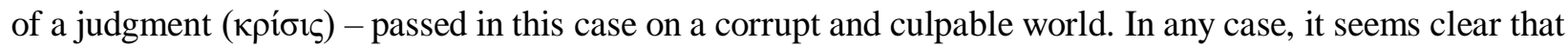
in most biblical apocalyptic literature, at least, true believers are assumed to be the victims of injustice and persecution in a world gone wrong. Members in good standing of the apocalyptic community are therefore represented as hoping to be rescued and/or vindicated as soon as possible (Rom 8:23; Rev 2:10, 6:10). Whether the aim is to respond to a crisis or to precipitate one, then, a situation of urgency is assumed. In either case, the message is that something is very wrong with anyone who doesn't see that something is very wrong.

From this point of view, the ultimate longed-for crisis in the sense of a judgment is a "Judgment Day" - a final divine intervention expected to set things right by force. For our purposes here, it should benoted that the earth itself plays a heartbreaking role in this drama. On the one hand, the entirety of creation can be seen as suffering and anxious to be delivered along with the faithful few (Rom 8:19). The earth's delivery from evil also includes, however, the cosmic "birth pangs" of a new creation being delivered (Mark 13:8; Rom 8:22-23). If we assume a single message behind the Bible's various apocalyptic passages (which Evangelicals characteristically do), the earth ultimately dies in this process of birth (Isa 65:17; 2 Peter 3:13; Rev 21:1-4) and takes a shocking beating along the way. A terrible suite of genocidal and ecocidal plagues are inflicted when the bowls of God's wrath are poured out, including at one point a punitive form of deliberate global warming: "The fourth angel poured out his bowl on the sun, and the sun was allowed to scorch people with fire. They were seared by the intense heat and they cursed the name of God, who had control over these plagues, but they refused to repent and glorify him" (Rev 18:8-9). The final cosmocide that clears the stage for "the new heavens and the new earth" is likewise imagined in fiery terms in texts like 2 Peter:

The day of the Lord will come like a thief, and then the heavens will pass away with a loud noise, and the elements will be dissolved with fire... Since all these things are to be dissolved in this way, what sort of persons ought you to be in leading lives of holiness and godliness, waiting for and hastening the coming of the day of God, because of which the heavens will be set ablaze and dissolved, and the elements will melt with fire? $(3: 10-12)$

In short, the divine plan is - to paraphrase the unnamed American general at Ben $\operatorname{Tre}^{21}$ - to burn the world in order to save it, and there is a marked tendency to look forward to the conflagration with a kind of eagerness that strikes some NT critics - including some Christian critics - as obscene. ${ }^{22}$ For those true

18. Leonard L. Thompson, The Book of Revelation: Apocalypse and Empire (New York: Oxford University Press, 1990), 27-28.

19. Elisabeth Schüssler Fiorenza, Revelation: Vision of a Just World (Minneapolis: Fortress Press, 1991), 92-102.

20. Steven J. Friesen, “Apocalypse and Empire," in The Oxford Handbook of Apocalyptic, ed. J. J. Collins (Toronto: Oxford University Press, 2014), 167.

21. Stephen L. Carter, "Destroying a Quote's History in Order to Save It," Bloomberg, February $9,2018$. https://www.bloomberg.com/opinion/articles/2018-02-09/destroying-a-quote-s-history-in-order-to-save-it.

22. David Frankfurter, "The Legacy of Sectarian Rage: Vengeance Fantasies in the New Testament," in Religion and Violence: The Biblical Heritage, ed. David A. Bernat and Jonathan Klawans (Sheffield: Sheffield Phoenix Press, 2007), 121; Stephen D. Moore, "The Revelation to John," in A Postcolonial Commentary on the New Testament Writings, ed. 
believers who chalk it all up to God's (better) judgment, though, everything is going according to plan. In fact, there is in a certain sense no crisis at all, no matter what may happen, since "all things work together for good for those who love God, who are called according to his purpose" (Rom 8:28). An unseen, unstoppable divine providence is always pulling strings behind the scenes, for the benefit of the elect. It's a conspiracy.

\subsection{Conspiracy}

Conspiracy theories purport, like Apocalypses, to reveal the astonishing inner workings of the world to a faithful few. ${ }^{23}$ By blaming social problems on nebulous scheming cabals, they allow people who feel powerless in some way to register discontent with the status quo and distrust of its authority figures. ${ }^{24}$ Conspiracy theories can in this way lend a dark but satisfyingly stark kind of meaning to confusing social problems, and make their proponents feel like members of a special group "in the know." ${ }^{25}$ The academic study of conspiracy theories has not yet been brought into conversation with the study of biblical apocalyptic. ${ }^{26}$ This looks like a mistake to me, given the functional affinity of the claims involved.

Apocalypses and conspiracy theories exhibit a number of parallel forms and functions. The book of Revelation assumes, for example, that Christians are the true heirs of the divine promises to Israel by virtue of knowing the true revealed (Jesus-centered) meaning of the traditional scriptures of Israel, and refers to Jewish scriptures at every opportunity. ${ }^{27}$ Revelation also assumes that Christians are being victimized by "those who say they are Jews, and are not, but are lying [because they belong to] the synagogue of Satan" (i.e., Jews who do not see the Jewish scriptures as cryptic witnesses to Jesus). ${ }^{28}$ In the picture thus painted, truth and authority are seen as flowing from expertise, but people with expertise who contradict the revelator are dishonest and evil. Insiders know a secret truth that is directly opposed to the

Fernando F. Segovia and R. S. Sugirtharajah (New York: T \& T Clark, 2007), 447; Tina Pippin, "The Revelation to John," in Searching the Scriptures, ed. Elisabeth Schüssler Fiorenza (New York: Crossroad, 1994), 109-130.

23. Ryan Neville-Shephard, "Paranoid Style and Subtextual Form in Conspiracy Rhetoric," Southern Communication Journal 83, no. 2 (2018): 119-132; J. E. Oliver and T. J. Wood, "Conspiracy Theories and the Paranoid Style(s) of Mass Opinion," American Journal of Political Science 58, no. 4 (October 2014): 952-966; Michael Barkun, A Culture of Conspiracy: Apocalyptic Visions in Contemporary America (Berkeley, CA: University of California Press, 2003), 1-14.

24. Neville-Shephard 2018, "Paranoid Style and Subtextual Form," 122-124; Barkun, A Culture of Conspiracy, 216-217; Jan-Willem van Prooijen and Nils B. Jostmann, "Belief in Conspiracy Theories: The Influence of Uncertainty and Perceived Morality," European Journal of Social Psychology 43 (2013): 109-115; V. Swami and R. Coles, "The Truth is Out There: Belief in Conspiracy Theories," The Psychologist 23 (2010): 560-563; Cass R. Sunstein and Adrian Vermeule, "Conspiracy Theories: Causes and Cures," Journal of Political Philosophy 17, no. 2 (2009): 202-227; Mark Fenster, Conspiracy Theories. Secrecy and Power in American Culture (Minneapolis: University of Minnesota Press, 2008), 9; Shane Miller, "Conspiracy Theories: Public Arguments as Coded Social Critiques: A Rhetorical Analysis of the TWA Flight 800 Conspiracy Theories," Argumentation and Advocacy 39 (Summer 2002): 51-53.

25. J. Hart and M. Graether, "Something's Going on Here: Psychological Predictors of Belief in Conspiracy Theories," Journal of Individual Differences 39, no. 4 (2018): 229-237; Karen M. Douglas, Robbie M. Sutton, and Aleksandra Cichocka, "The Psychology of Conspiracy Theories," Current Directions in Psychological Science 26, no. 6 (2017): 538542; Roland Imhoff and Pia Karoline Lamberty, "Too Special to be Duped: Need for Uniqueness Motivates Conspiracy Beliefs," European Journal of Social Psychology 47, no. 6 (2017): 724-734; Jan-Willem van Prooijen, "Sometimes Inclusion Breeds Suspicion: Self-Uncertainty and Belongingness Predict Belief in Conspiracy Theories," European Journal of Social Psychology 46 (2016): 267-279; Jovan Byford, Conspiracy Theories: A Critical Introduction (New York: Palgrave Macmillan, 2011), 139-142.

26. For example, none of the otherwise excellent sources on Revelation cited in this study explicitly discuss conspiracies or conspiracy theories, let alone theories of conspiracy theory.

27. Albert Vanhoye, "L'Utilisation du livre d'Ézéchiel dans L'Apocalypse," Biblica 43 (1962): 439; Josephine Massyngberde Ford, Revelation (Garden City, NY: Doubleday, 1975), 27.

28. $\operatorname{Rev} 3: 8-10$. 
common-sense public consensus, and outsider experts who disagree are the puppets of the Devil. This is textbook conspiracy-theory thinking. ${ }^{29}$ The common-sense consensus reality of the world outside is mocked and derided as an oppressive distortion of the truth. The corrupt powers that be pose a constant threat to the faithful few precisely because their grotesque system is threatened by this truth. Notice, too, what the Son of Man promises: if the elect will hold fast, their oppressors will one day be forced to fall and worship at their feet. Insiders are paradoxically, doubly ennobled as both victims and victors by virtue of being "in the know." This too is textbook conspiracy-theory thinking. ${ }^{30}$

The fact that the "so-called Jews" of Revelation are linked to a multi-tentacled global "Synagogue of Satan" ${ }^{31}$ provides a useful reminder here: God is not imagined as alone in his constant scheming. Satan and his minions are conspiring in an equal and opposite way against the elect. The "false Prophet" whose power flows from preaching false divine revelations supplies a dark shadow for the figure of the revelator (Rev 13:11-14). ${ }^{32}$ The Devil's disciples have even infiltrated the community of the faithful itself and "misled many" (Rev 2:20). Satan, for his part, is "the deceiver of the whole world" (Rev 12:9). On the other hand, true believers are also part of a global conspiracy (in line with the finding that conspiracy theorists are more tempted than others to conspire) ${ }^{33}$ Proper community insiders conspire against the powers that be by praying together with all the saints living and dead for the end to come soon (Rev 6:9-11;22:20), and as we just saw in 2 Peter they actively hasten the day on which the heavens and earth will burn by living holy lives. They are in this sense God's co-conspirators, participating in the advent of their preferred global crisis by acting like proper members of the community of the elect.

\subsection{Community}

From a social-scientific point of view, apocalyptic imagination is a powerful and versatile tool for the construction of identity in contradistinction to the world defined as "outside" the community of the elect. ${ }^{34}$ The relevance of crises and conspiracies to such projects of identity definition is obvious. Conspiracy theories are infamous for their "polarizing" and "self-insulating" insider/outsider logic. ${ }^{35}$ Once true believers have internalized a conspiracy-minded "us-versus-them" picture of the world, even "attempts to dispel the theory can usually be folded into the theory itself." ${ }^{36}$ Unwelcome ideas, arguments, facts, and

29. See, for example, the conspiracy-theory phenomenon of "fact-fiction reversal" discussed by Barkun, A Culture of Conspiracy, 29-33.

30. See Sunstein and Vermeule, "Conspiracy Theories: Causes and Cures."

31. Rev 2:9; 3:9.

32. See also Matthew 24:36; 2 Thessalonians 2:11, etc.

33. Karen M. Douglas and Robbie M. Sutton, "Does it Take One to Know One? Endorsement of Conspiracy Theories is Influenced by Personal Willingness to Conspire, British Journal of Social Psychology 50 (2011): 544-552.

34. Philip F. Esler, "Social-Scientific Approaches to Apocalyptic Literature," in The Oxford Handbook of Apocalyptic Literature, ed. J. J. Collins (Toronto: Oxford University Press, 2014), 123-144; Anthea Portier-Young, Apocalypse against Empire: Theologies of Resistance in Early Judaism (Grand Rapids, MI: Eedrmans, 2011); Richard A. Horsley, Revolt of the Scribes: Resistance and Apocalyptic Origins (Minneapolis: Fortress, 2010); David A. deSilva, "The Revelation to John: A Case Study in Apocalyptic Propaganda and the Maintenance of Sectarian Identity," Sociological Analysis 53 (1992): $375-$ 395; Wayne A. Meeks, "Sociological Functions of Apocalyptic Language in Pauline Christianity," in Apocalypticism in the Mediterranean World and the Near East: Proceedings of the International Colloquium on Apocalypticism, Uppsala, August 12-17, 1979, ed. David Helholm (Tübingen: Mohr Siebeck, 1983), 687-705; G. W. E. Nickelsburg, "Social Aspects of Palestinian Jewish Apocalypticism," in Hellholm, Apocalypticism in the Mediterranean World and the Near East, $641-654$. 35. Sunstein and Vermeule, "Symposium on Conspiracy Theories," 216-217.

36. Sunstein and Vermeule, "Symposium on Conspiracy Theories," 210. 
figures are simply dismissed as new tricks devised by "them." ${ }^{37}$ Crises are similarly famous for their ability to create tight communities. ${ }^{38}$ When people feel threatened by a common crisis, they are especially willing to believe that "the enemy of my enemy is my friend."

For such reasons, the social dynamics of crisis and conspiracy amplify the identity-defining function of apocalyptic imagination. The "chosen few" to whom the truth of the end is revealed are offered a chance to see and comport themselves as belonging to a special group of insiders, defined over against the ignorant, corrupt, and doomed world outside. The down-to-earth attractiveness of the unearthly visions found in apocalyptic sources like Revelation is therefore found partly in their offer of somebody special to be, and somewhere special to belong. As the next section shows, these sociological dynamics of crisis, conspiracy and community are central to the evolution and success of twentieth century Christian pop apocalyptic as well, in ways that shed helpful light on the phenomenon of Evangelical climate denial.

\subsection{Crisis, Conspiracy, and Community in Evangelical Pop Apocalyptic}

Evangelical pop apocalyptic was born in the USA with the movement's embrace of the "Darbyist" method of biblical interpretation, ${ }^{39}$ and is alive and well in the kind of end-time millennialism and paranoia of the blockbuster Left Behind series of books and movies (1995-2016). ${ }^{40}$ In this section, I describe the apocalyptic faces of crisis, conspiracy and community in the work of best-selling Evangelical cartoonist Jack T. Chick (1924-2016). Although his sensationalist and inexpensive comics have made him quite possibly "the world's most published author," ${ }^{41}$ Chick's name is echoingly absent from the record in academic Religious/Biblical Studies. His illustrated pamphlets are inexpensive and "ubiquitous" 42 enough to strike some as a "littering" problem, ${ }^{43}$ so they may have simply managed to fly under the academic Religious/Biblical Studies radar as disposable trash. Scholars may also be reluctant to dignify such cut-rate "hate literature and fire-and-brimstone sermonizing" 44 with serious attention.

For whatever reason, scholarship on Evangelical eschatology and apocalypticism abounds with references to the Left Behind phenomenon, ${ }^{45}$ but fails to give Jack T. Chick even a passing mention. This scholarly neglect amounts to a significant pop culture blind spot. When Tim Lahaye died, his Left Behind

37. Sunstein and Vermeule, "Symposium on Conspiracy Theories," 225; Daniel Jolley and Karen M. Douglas, "The Effects of Anti-Vaccine Conspiracy Theories on Vaccination Intentions," Plos ONE 9, no. 2 (2014): e89177.

38. Rebecca Solnit, A Paradise Built in Hell: The Extraordinary Communities That Arise in Disaster (New York: Penguin, 2010).

39. Craig R. Koester, Revelation, 60-61.

40. Nancy A. Schaefer, "The Left Behind Series and Its Place Within the American Evangelical Subculture," in End of Days: Essays on the Apocalypse from Antiquity to Modernity, ed. Karolyn Kinae and Michael A. Ryan (Jefferson, NC: McFarland, 2009), 290.

41. Robert Ito, "Fear Factor: Jack Chick is the World's Most Published Author - And One of the Strangest," Los Angeles Magazine, May 2003, 56; Kurt Kuersteiner, The Unofficial Guide to the Art of Jack T. Chick (Atglen, PA: Schiffer Publishing, 2004), 7.

42. Mark Dery, “All About Evil” Jack Chick’s Fire and Brimstone,” Village Voice Literary Supplement, April $1992,27$.

43. Lance Weldy, "Graphically/Ubiquitously Separate: The Sanctified Littering of Jack T. Chick's Fundy-Queer Comics," in Graphic Novels for Children and Young Adults: A Collection of Critical Essays, ed. Michelle Ann Abate and Gwen Athene Tarbox (Jackson, MS: University of Mississippi Press, 2017), 273.

44. Ito, "Fear Factor."

45. Forbes, "How Popular Are the Left Behind Books... and Why?", 5-32; Sutton, American Apocalypse, 363-365, 369, 371; Timothy P. Weber, "Millenialism," in The Oxford Handbook of Eschatology, ed. J. L. Walls (Toronto: Oxford University Press, 2008), 379; Robert Jewett and John Shelton Lawrence, "Eschatology in Pop Culture," in The Oxford Handbook of Eschatology, ed. J. L. Walls (Toronto: Oxford University Press, 2008), 663-664; DiTomasso, “Apocalypticism 
series boasted 80 million units sold. ${ }^{46}$ When Chick died the same year, his self-published catalogue had climbed to 800 million units sold, leading creator-critic Daniel Raeburn to describe Chick - only halfjokingly - as "the most widely-read theologian in human history." 47 As Christianity Today once noted, Chick tracts often speak to and for "the world of ordinary, unlearned evangelicals." 48 If apocalyptic conspiracy theories are an Evangelical pandemic, then, the academy would be well advised to treat Chick publications as both a significant symptom and an important vector. In this section, I describe two of Chick's tracts - The Last Generation (1972/1992) and Global Warming? (2012) - to trace the way their twentieth century Evangelical brand of pop apocalyptic articulates ideal insider identity in terms of crisis and conspiracy.

\subsection{Crisis}

In my Introduction, I noted a kind of equivocation in conspiracy-minded apocalyptic climate denial that allows its Evangelical proponents to have their crisis and deny it too. They claim to know a priori that there is no life-and-death climate emergency for people to take action on, because God has other plans for the end of the world as we know it (which may well include cataclysmic global warning, if it is indeed real). The terrible krisis of God's coming judgment is, on the other hand, a real and pressing concern, but it is a good thing, not a bad thing. From this point of view, then, the most immediate global threat is the diabolical scheming of the earthly powers that be, who treat the elect terribly and threaten worse to come. This selfinsulating, self-martyrizing brand of climate denial has been marketed aggressively over the years in the Evangelical pop apocalyptic of Jack T. Chick's tracts.

The publications under examination here span four decades to the year. Chick released The Last Generation in 1972 and updated it twenty years later in 1992. Global Warming? came out another twenty years later in 2012. Although the details change over time, the apocalyptic conspiracy-theory thinking that drives Evangelical climate denial remains remarkably constant: human authorities are wrong to threaten and plot against the elect, and also wrong to think that human action can save the world. In the first edition of The Last Generation, global pollution is apparently a real threat. People cover their faces and struggle to breathe the hazy air when they go outside, while inside the "government-controlled television sets" make Orwellian and strangely wooden announcements about the situation: "Good news... Science will soon solve the ecology crisis." The government gospel rings hollow to the story's oppressed Christian heroes, though ("With what?" - one asks - "A magic wand?"), and the story is cut short anyway by the thermonuclear fire of World War III. This "one day fire war" (identified in a footnote with the curse that burns up the earth's inhabitants in Isaiah 24:6 and the fire that falls from the sky in Revelation 8:7) arrives just seconds after anti-Christian government forces break down the door to find that the Christians have been safely raptured

and Popular Culture"; Amy Johnson Frykholm, "Apocalypticism in Contemporary Christianity," The Oxford Handbook of Apocalyptic Literature, ed. J. J. Collins (Toronto: Oxford University Press, 2014), 450; Jennie Chapman, "Selling Faith Without Selling Out: Reading the Left Behind Novels in the Context of Popular Culture," in The End is All Around Us: Apocalyptic Texts and Popular Culture, ed. John Wallis and Kenneth G. C. Newport (Oakville, CT: Equinox, 2009), 148172; Schaefer, "The Left Behind Series."

46. Todd Starowitz, "Tim LaHaye, Left Behind Coauthor and Evangelical leader, Passes at 90," Left Behind Official Website, July 25, 2016. http://leftbehind.com/05_news/tim-lahaye-passes-at-90.asp.

47. Daniel Raeburn, The Imp \#2 (Chicago, IL: Self-published, 1998), 1.

48. Mark Noll and Carolyn Nystrom, "Is the Reformation Over?," Christianity Today, July 1, 2005, https://www.booksand culture.com/articles/2005/julaug/1.10.html. 
away to heaven. In The Last Generation, the end is indeed near - as it always is in Chick's comics ${ }^{49}-$ but it is in the hands of God alone.

Chick's non-narrative tract Global Warming? pushes the kinds of apocalyptic conspiracy theories just described more explicitly. Chick addresses the reader directly, to explain that humans who believe they can change the climate are "only fooling themselves," promises that in the last days humanity will be "scorched with great heat" (Rev 16:9) and "the earth... will be burned up" (2 Peter 3:10). In celebrating fiery global judgment as a good and unavoidable thing, Chick casts himself as a true prophet with the right to announce judgment on doubters. One panel portraying atheists and other miscreants is subtitled in capital letters with the words "IT'S PAYBACK TIME!" Climate experts, on the other hand, are cast as false prophets who mistakenly and arrogantly pass judgment on the doubtful. In the tract's first panel, Al Gore points his finger at the viewer, and says, "We warned you, but you ignored us. Now you will pay the price."

By rhetorically aligning apocalyptic dogmatism with climate science skepticism, The Last Generation and Global Warming? depict the elect as both powerful and persecuted. From Chick's point of view, the fake crisis of climate change exacerbates the real crisis of anti-Christian persecution. In The Last Generation, the government of the Anti-Christ that promises the ecology crisis can be solved by science also announces in the same breath that Christians are heretics in the eyes of the "Church of World Brotherhood" and therefore "enemies of the state." In Global Warming? false prophets declare a similar war on Christians: "Global warming experts pray to Ixchel and Gaia for guidance, not your Jesus," raves one hysterical climate expert. "This is our planet!" Chick responds that God will soon put such false prophets in their place, and adds that the ultimate source of the fake crises that create the real ones is the endless scheming of Satan, who always furthers God's secret end-time plans despite himself. Whenever "the father of lies" perpetrates anti-Christian hoaxes like climate change using his puppets in high places, Chick explains, "powerful, unseen forces push us ever closer to fulfilling God's prophecies." It's a conspiracy.

\subsection{Conspiracy}

Scholars interested in American conspiracy theories have acknowledged Evangelical pop apocalyptic as an important vector, ${ }^{51}$ but so far Religious Studies scholars studying Evangelical pop apocalyptic have not returned the courtesy. When it comes to addressing Evangelical climate denial, failing to consider the characteristic dynamics of conspiracy-theory thinking is an especially bad idea. For one thing, conspiracy theories of any kind seem to drain people of the will to take action on the climate, presumably by encouraging feelings of suspicion and practical helplessness. ${ }^{52}$ Moreover, as I stressed in my introduction, Evangelical climate skeptics do not limit their skepticism to cultivating an "unconvinced" pose. They also dependably express a positive belief that somebody is pulling strings behind the scenes.

49. Kuersteiner, The Art of Jack T. Chick, 10.

50. Global Warming?, 13.

51. See, for example, Barkun, A Culture of Conspiracy, 15-38, 110-125; Robert Alan Goldberg, Enemies Within: The Culture of Conspiracy in Modern America (New Haven: Yale University Press, 2001), 66-104.

52. Daniel Jolly and Karen M. Douglas, "The Social Consequences of Conspiracism: Exposure to Conspiracy Theories Decreases Intentions to Engage in Politics and to Reduce One's Carbon Footprint," British Journal of Psychology 105 (2014): $35-36$. 
Conspiracy theories abound in Chick tracts, as they do in his other publications and personal correspondence. ${ }^{53}$ The evil global plots in question always involve Satan, Satanists, and/or the Vatican, ${ }^{54}$ since Chick has always insisted that the Catholic Church is the Whore of Babylon described in Revelation ${ }^{55}$ and the Pope is an Antichrist bent on establishing the one-world government of the Devil. ${ }^{56}$ One of Chick's anti-Catholic comic books (The Godfathers, 1982) pushes this paranoid apocalyptic vision to dizzying heights of meta-conspiracy theory, by claiming to reveal that all of the other conspiracy theories in the world are fictions cooked up and planted in pop culture by the Vatican, to draw attention away from their own real global conspiracy against God and God's faithful few.

In The Last Generation and Global Warming, Chick brings this typical brand of conspiracy-theory logic into explicit conversation with questions of climate emergency and the end of the world. In the 1972 edition of The Last Generation, a wise Christian grandfather explains to a family huddled against the hostile environment and government outside that the increasing persecution of Christians is the visible face of a "godless, power-mad conspiracy." "The forces of Anti-Christ are closing in," he explains, because biblical prophecy (Matthew 24:32-34) requires the end of the world to happen one generation after the establishment of the nation of Israel in 1948. In 1982, Chick "hedged and added a footnote" cautioning that biblical scholars were divided about how many years make up a generation, and in later editions of The Last Generation he quietly drops his dating prediction entirely, ${ }^{57}$ but the basic picture remains the same twenty years later in The Last Generation of 1992. Crises like "persecution, new killer diseases, earthquakes and wars all over" signal, the grandfather reveals, that "this could be THE LAST GENERATION! That's why I'm so excited!"

Twenty more years later, in Global Warming?, questions of climate emergency remain linked in Chick's Evangelical apocalyptic imagination to anti-Christian conspiracies. "Back in the Dark Ages," the tract says, the Catholic church used end-of-the-world threats to fleece the gullible: they accepted lavish gifts of penance offered as protection against the day of judgment slated for the year 1000, and then refused to give people their property back when the doomsday date came and went. Global Warming? dismisses modern science-based climate alarm as a similar hoax foisted on the public by "prophets of doom," by equating a list of environmentalist predictions that turned out to be wrong to the failed prophecy (attributed to Nostradamus) that the world would end in 1999.

Chick ignores the significance of the fact that the predictions in question all came from individuals (some untrained in climate science). None of the speculations in question ever represented the global scientific consensus. He does not know or does not care, either, that Nostradamus predicted the arrival of "a great king of terror" in 1999 - not the end of the world. ${ }^{58}$ Chick certainly does not mention his own failed prediction concerning the date of the end of the world, mentioned above. For his purposes, the important thing is to stress that prophets of doom "outside" the one true Evangelical faith have done wrong and been

53. Kuersteiner, The Art of Jack T. Chick, 7, 18-27, 95; Raeburn, The Imp, 4; Robert B. Fowler, The World of Chick? (San Francisco, CA: Last Gasp, 2001), 1-2.

54. Kurt Kuersteiner, The Art of Jack T. Chick, 7-8, 17-31; Gina Misiroglu, ed., American Countercultures: An Encyclopedia of Nonconformists, Alternative Lifestyles, and Radical Ideas in U.S. History (New York: Routledge, 2009), 146-147.

55. Kuersteiner, The Art of Jack T. Chick, 10.

56. Kuersteiner, The Art of Jack T. Chick, 10.

57. Fowler, The World of Chick?, 3-39.

58. "Du ciel viendra un grand Roi deffraieur," is the actual wording of the prediction found in 10.72. See Nostradamus: The Prophecies. A Dual-Language Edition with Parallel Text, trans. Richard Sieburth (New York: Penguin, 2012 ), 286. 
wrong before. Their diabolical scheming, their hatred for the truth and the elect, and their constant failed prophetic posturing all highlight the sharp identifying line between "us" and "them."

\subsection{Community}

In 2019, Robin Globus Veldman published the results of a fourteen-month investigation into what she diplomatically called "Evangelical climate skepticism." Based on the way her interviewees consistently baptized their various forms of climate denial as a characteristically Christian stance that highlighted the evangelical community's "witness" status over against the world outside, Veldman concluded that Evangelical climate denial needs to be recognized as a sociological phenomenon. Evangelical Christian beliefs about the end of the world (which Veldman found to vary significantly) are, she writes, credited too generously and uncritically in most discussions of the problem. ${ }^{59}$ From the point of view outlined in the sections above, Veldman is mostly right.

Veldman's first conclusion - that Evangelical climate denial is related to the definition and assertion of an oppositional, "embattled" identity - is significant for the purposes of this study partly because such denial is so often expressed in the language of apocalyptic conspiracy theory. As the opinion surveys cited above show, ${ }^{60}$ and as Veldman's report confirms, ${ }^{61}$ Evangelicals do not limit their opposition to climate action to the negative forms of selective doubt and an "unconvinced" pose. They also express a positive belief that some kind of global conspiracy is afoot. Such selective skepticism in the face of global scientific consensus is typical conspiracy theory thinking, and as noted already above conspiracy theories typically offer people the attractive group identity of special people "in the know." For this reason, when Veldman draws her second conclusion - that Evangelical apocalyptic beliefs are not as clearly central to the problem as commonly thought - she might be missing a part of her own point. As I stressed above, Evangelicals who deny the reality and/or urgency of climate change dependably cite their end-time beliefs as relevant. ${ }^{62}$ From the point of view outlined in this study, they presumably do so precisely because apocalyptic imagination - including in this case the strategic reworking of material from the book of Revelation - lends itself so well to projects of defining satisfying "insider" identity.

I argued above in discussing biblical apocalyptic culture that much of the popular allure of apocalyptic crises and conspiracy theories lies in their potential for defining identity. The romantic picture they paint of a beleaguered but beloved community of the elect offers audiences a somebody special to be, and something to belong to, since almost anyone can play victim and victor at the same time by reading a text like Revelation as the story of their own martyrdom and coming vindication. "The anticipated reversal of 'ordinary history' is a source of great comfort for millions of true believers," as Scott Appleby once noted, "whether they live in the putrid refugee camps of Gaza or southern Lebanon, or amid the relative affluence of the spiritually sterile suburbs of Dallas." ${ }^{" 33}$ Chick's tracts The Last Generation and Global

59. Veldman, The Gospel of Climate Skepticism, 25-46, 69-85.

60. Carr et al., "The Faithful Skeptics," 289, 292-293.

61. Veldman, The Gospel of Climate Skepticism, 107-108.

62. Veldman, The Gospel of Climate Skepticism, 69, 72-75, 82-85; Stover, "Evangelicals for Climate Action," 70, 293; Roser-Renouf et al., "Global Warming, God and the 'End Times"”; Jones et al., "Believers, Sympathizers, and Skeptics," 4, 23-24; Barker and Bearce, "End-Times Theology," 269; Carr et al., "The Faithful Skeptics," 293; Rossing, "Hastening the Day When the Earth Will Burn," 25-38; Zaleha and Szasz, "Why Conservative Christians Don't Believe in Climate Change," 19-30.

63. Scott Appleby, "The Unholy Uses of Apocalyptic Imagination: Twentieth Century Patterns," in Apocalypse and Violence, ed. Abbas Amanat and John J. Collins (New Haven: The Yale Center for International and Area Studies and the Council on Middle East Studies, 2002), 75. 
Warming? are useful once again here, as illustrations of the way this insider-defining potential of apocalyptic imagination can work on the ground in the context of Evangelical pop culture.

The invitation to be part of a special insider group is always made quite explicit in Chick's tracts, since the closing pages always reach out to the reader with the direct address of an illustrated altar call. ${ }^{64}$ The 1972 edition of The Last Generation accordingly closes with "Christ's promise to his own" found in Revelation 3:10-11: "I also will keep thee from the hour of temptation, which shall come upon all the world, to try them that dwell upon the earth. Behold, I come quickly." Chick comics assume an absolute categorical line between "the saved" and "the lost," 65 and their juxtaposed promises of eternal bliss for theformer and eternal torture for the latter effectively do the double duty of sealing and ennobling saved readers as insiders while harrying outsiders to hurry in. ${ }^{66}$ Readers are urged to make sure they are on the right sideof the lost/saved line, with the Christian family of The Last Generation reported to the authorities by the bad seed grandson Bobby. "DID YOU ACCEPT CHRIST AS YOUR OWN PERSONAL SAVIOR?" thefinal page demands. The 1992 edition of The Last Generation is even more explicit: "Little Bobby died inhis sins. DON'T BE FOOLED LIKE BOBBY. Trust Christ today so you'll be ready for the Blessed Hope."The invisible universal community of the elect stands firm on the "saved" side of the end-time line precisely because they are not fooled by the threats and promises of the Devil's puppets in the high places of science and government.

Global Warming? applies the conspiracy-theory insider/outsider logic of The Last Generation to questions of climate emergency still more explicitly. I referred above to the image of the climate expert included in the tract. "Global warming experts pray to and Ixchel and Gaia for guidance. Not your Jesus," she fumes. "This is our planet!" The italics are in the original, underlining the "us" versus "them" dynamic set up by the first pages. On the first page, Al Gore talks down to the readerly "you" four times in three sentences, twice in bold and once in italics. "We warned you," he says on behalf of climate experts, "but you ignored us." The second page continues hammering on this us/them contradistinction from the other side, opposing the everyman "us" group of Chick and his readers to an arrogant "them" group full of judgmental prophets of doom: "Brilliant scientists graciously counsel us 'little people' on climate changes and the coming dangers of global warming. Are they right? Is Mother Earth doomed because of us? They must be right, because they're "scientists!" Hmm... Let's think about this.",67

For Chick's purposes in Global Warming?, the invitation to think about climate change entails arguing at length that the apocalyptic visions of those outside the true faith are wrong as usual, since the Devil is working overtime to deceive in these last days, and since the "real global warming" to come must inevitably happen on the Day of the Lord when "the earth shall be burned up" (2 Peter 3:10). Chick closes the discussion by extending his usual invitation to join the elect and avoid the fate of people like the boy who was fooled by Satan and "died in his sins" in The Last Generation. "After this, all who died in their sins will be brought up from hell and face Jesus and their judge on Doomsday," Chick explains without apparent embarrassment about his own unverifiable announcements of judgment and doom, citing Revelation (14:11, 20:11-13, and 20:15) and warning, "Don't let this happen to you!" In this way, Global Warming? affirms once again the pop apocalyptic imagination and conspiracy-theory thinking that inform the

64. See the pictorial history of the "Inside Back Cover" pages collected in Fowler, The World of Chick?, Appendix F, 8-15. 65. Martin Lund, “'[A] Matter of SAVED or LOST': Difference, Salvation, and Subjection in Chick Tracts," in Comics and Power: Representing and Questioning Culture, Subjects, and Communities, ed. Rikke Platz Cortsen, Erin La Cour, and Anne Magnussen (Newcastle upon Tyne: Cambridge Scholars Press, 2015), 179.

66. Lund, "[A] Matter of SAVED or LOST," 186.

67. Italics added for emphasis. 
Evangelical brand of climate denial, defining insiders as a noble group mercifully blessed with too much wisdom to be fooled by the diabolical pseudo-prophecies of worldly authorities.

\section{Conclusion}

I have argued here that the political and theological phenomenon of Evangelical climate denial has a sociological center of gravity. The down-to-earth attraction of all the heady apocalyptic imagination and conspiracy-theory thinking associated with Evangelical climate denial is the opportunity such visions offer to articulate and assert satisfying ideas of insider identity. To provide a summary overview of the sociorhetorical dynamics involved, I traced two related constellations of crisis, conspiracy, and community in biblical apocalyptic and in the derivative modern brand of Evangelical pop apocalyptic represented in the tracts of Jack T. Chick. In both cases, I argued that defining crises using apocalyptic imagination and conspiracy-theory thinking had the practical advantage of defining community. The ennobling pictures of insider status painted in such texts invite audiences to be somebody special by belonging to something special defined in contradistinction to the corrupt and doomed world outside.

Assessing the strange and dangerous normalcy of Evangelical climate denial in this way has meaningful implications for the question of how to address it. If one of the dynamics driving Evangelical climate denial is a conspiracy-theory logic of "us versus them" that makes insiders feel like special people "in the know," probably the most important implication is that the common response of responding with salvos of evidence and argument will practically never work - especially when such opposition is perceived as coming from the "outside." As noted above, conspiracy theories are self-insulated against the criticism of outsiders, and can in fact feed on it. Jack T. Chick positively reveled, for example, in the terrible social "price" of his call to speak out, citing Luke 6:26: "Woe unto you when all men shall speak well of you, for so did their fathers to the false prophets." ${ }^{, 68}$ Evangelicals like Chick are addicted, in short, to "a megalomania reveling in underdog status" 69 informed by the apocalyptic victim/victor complex discussed above. "I routinely ask my secretary if we are getting any hate mail," he once boasted/confessed: "If she says no, I get upset because I think I'm doing something wrong."70

Given the psycho-social dynamics involved, it may be that concerned parties hoping to defuse Evangelical climate denial will get the best results in the end by fighting fire with fire, sociologically speaking. Instead of providing evidence and argument that will almost certainly be dismissed as defending and depending upon "outside" authorities and "outside" values, they can provide competing opportunities for Evangelical insiders to belong and feel special. From this point of view, "insider" initiatives like the Southern Baptist Declaration on the Environment and Climate Change have real potential. There is good evidence that Evangelicals can be attracted to environmental values when they are expressed in terms of a specifically Christian commitment to a biblical duty of "creation stewardship,"71 and the Declaration sweetens the deal with insider-ennobling calls to guard the community's unique revelation and to be more morally exemplary than the world outside. "Each generation of Christians bears the responsibility of guarding the treasury of truth that has been entrusted to us (2 Timothy 1:14) [...] To abandon these issues to the secular world is to shirk from our responsibility to be salt and light [i.e. a small minority with a big

68. Jack T. Chick, “Let's Make a Stand.” Self-published audio recording, 1981. Available online at https://www. youtube.com/watch?v=BdA_QL8j6LY.

69. Raeburn, The Imp, 16.

70. Raeburn, The Imp, 6.

71. Stover, "Evangelicals for Climate Action," 66-72. 
moral impact]." 72

Responses to Evangelical climate denial of the kind just described may vary as much as the denial does. When Barbara Rossing exhorts Christians to embrace the "new creation" of Revelation as arestoration (not a replacement) in opposition to the glorification of global destruction found in 2 Peter, sheis in a sense calling for a little green-apocalyptic Reformation and a special community - a kind of Christianity within Christianity openly excited about hastening the destruction of global injustice as opposed to the globe itself. In a similar vein, the online community called "Red Letter Christians" recently blasted "most evangelicals" for hiding their heads in the sand of apocalyptic fantasy like the Left Behind series instead of leading a "biblical" charge against climate change. "Biblical eschatology," they enthused, "should cause Christians to be the most hopeful climate activists on the planet." 73 For our purposes here, it is worth noting that they call their Evangelicalism-within-Evangelicalism a "Red Letter Christian" movement because some Bibles print the words of Jesus in red, and they describe their community as committed to "taking the words of Jesus seriously" (which they condemn most Christians as unwilling to do). This kind of pop culture response may, like the Southern Baptist Declaration, be able to damage the apocalyptic conspiracy-theory thinking of Evangelical climate denial where it counts - i.e., in its ability tomake people feel special by virtue of their insider status in the community of the faithful few. Whatever they may look like in detail, and however those of us who continue to be left outside may feel about them, such fire-against-fire strategies may provide a way for Evangelicals to join their concerned fellow citizensin acknowledging and acting on the realities of climate change, instead of being left behind.

72. Southern Baptist Convention, "Full Text of SBECI Declaration.” March 10, 2008. http://www.bpnews.net/27585/fulltext-of-sbeci-declaration. Italics added for emphasis.

73. Don Golden, "Left Behind: How End Times Heresies Undermine Evangelical Action on Climate," Red Letter Christians Website, September 24, 2019. 


\section{Bibliography}

Alumkal, Antony. Paranoid Science: The Christian Right's War on Reality. New York: New York University Press, 2018.

Appleby, Scott. "The Unholy Uses of Apocalyptic Imagination: Twentieth Century Patterns.” In Apocalypse and Violence, 69-87. Edited by Abbas Amanat and John J. Collins. New Haven: The Yale Center for International and Area Studies and the Council on Middle East Studies, 2002.

Barker, David C. and David H. Bearce. "End-Times Theology, the Shadow of the Future, and Public Resistance to Addressing Global Climate Change." Political Research Quarterly 66, no. 2 (2013): 267-279.

Barkun, Michael. A Culture of Conspiracy: Apocalyptic Visions in Contemporary America. Berkeley, CA: University of California Press, 2003.

Byford, Jovan. Conspiracy Theories: A Critical Introduction. New York: Palgrave Macmillan, 2011.

Carr, Wylie, Michael Patterson, Laurie Yung, and Daniel Spencer. "The Faithful Skeptics: Evangelical Religious Beliefs and Perceptions of Climate Change." Journal for the Study of Religion, Nature and Culture 6, no. 3 (2012): 276-299.

Carter, Stephen L. "Destroying a Quote's History in Order to Save It.” Bloomberg, February 9, 2018. https://www.bloomberg.com/opinion/articles/2018-02-09/destroying-a-quote-s-history-in-orderto-save-it.

Chapman, Jennie. "Selling Faith Without Selling Out: Reading the Left Behind Novels in the Context of Popular Culture." In The End is All Around Us: Apocalyptic Texts and Popular Culture, 148-172. Edited by John Wallis and Kenneth G. C. Newport. Oakville, CT: Equinox, 2009.

Charlesworth, James H. "Introduction." In The Old Testament Pseudepigrapha Vol. 1: Apocalyptic Literature and Testaments. Edited by J. H. Charlesworth. Peabody, MA: Hendrickson, 1983.

Cheney, Jillian. "Why Many Evangelicals Believe Climate Change Is A Hoax.” Religion Unplugged, September 27, 2019. https://religionunplugged.com/news/2019/9/27/climate-change-and-evangeli cals-why-do-so-many-of-them-believe-its-a-hoax.

Cheung, Helier. "What Does Trump Actually Believe on Climate Change?” BBC News, January 23, 2020. https://www.bbc.com/news/world-us-canada-51213003.

Collins, John J. "Apocalyptic Eschatology in the Ancient World.” In The Oxford Handbook of Eschatology, 40-55. Edited by J. L. Walls. Toronto: Oxford University Press, 2008.

—. "What is Apocalyptic Literature?" In The Oxford Handbook of Apocalyptic Literature, 1-18. 
Edited by J. J. Collins. Toronto: Oxford University Press, 2014.

Dery, Mark. ““All About Evil’ Jack Chick’s Fire and Brimstone.” Village Voice Literary Supplement, April 1992.

deSilva, David A. "The Revelation to John: A Case Study in Apocalyptic Propaganda and the Maintenance of Sectarian Identity.” Sociological Analysis 53 (1992): 375-395.

DiTomasso, Lorenzo. “Apocalypticism and Popular Culture." In The Oxford Handbook of Apocalyptic Literature, 473-509. Edited by J. J. Collins. Toronto: Oxford University Press, 2014.

Douglas, Karen M., and Robbie M. Sutton. "Does it Take One to Know One? Endorsement of Conspiracy Theories is Influenced by Personal Willingness to Conspire.” British Journal of Social Psychology 50 (2011): 544-552.

—., Robbie M. Sutton, and Aleksandra Cichocka. "The Psychology of Conspiracy Theories." Current Directions in Psychological Science 26, no. 6 (2017): 538-542.

Esler, Philip F. "Social-Scientific Approaches to Apocalyptic Literature.” In The Oxford Handbook of Apocalyptic Literature, 123-144. Edited by J. J. Collins. Toronto: Oxford University Press, 2014.

Fenster, Mark. Conspiracy Theories: Secrecy and Power in American Culture. Minneapolis: University of Minnesota Press, 2008.

Fitzgerald, Frances. The Evangelicals: The Struggle to Shape America. Toronto: Simon and Schuster, 2017.

Fowler, Robert B. The World of Chick? San Francisco, CA: Last Gasp, 2001.

Frankfurter, David. "The Legacy of Sectarian Rage: Vengeance Fantasies in the New Testament." In Religion and Violence: The Biblical Heritage, 114-128. Edited by David A. Bernat and Jonathan Klawans. Sheffield: Sheffield Phoenix Press, 2007.

Friesen, Steven J. “Apocalypse and Empire.” In The Oxford Handbook of Apocalyptic Literature, 163-179. Edited by J. J. Collins. Toronto: Oxford University Press, 2014.

Frykholm, Amy Johnson. "Apocalypticism in Contemporary Christianity." In The Oxford Handbook of Apocalyptic Literature, 441-456. Edited by J. J. Collins. Toronto: Oxford University Press, 2014.

Funk, Cary, and Becka A. Alper. "Religion and Views on Climate and Energy Issues." Pew Research Center, October 22, 2015. https://www.pewresearch.org/internet/wp-content/uploads/sites/9/2015 /10/PI 2015-10-22 religion-and-science FINAL.pdf.

Globus Veldman, Robin. The Gospel of Climate Skepticism: Why Evangelical Christians Oppose Action on Climate Change. Oakland, CA: University of California Press, 2019. 
Goldberg, Robert Alan. Enemies Within: The Culture of Conspiracy in Modern America. New Haven: Yale University Press, 2001.

Hart, Joshua and Molly Graether. "Something's Going on Here: Psychological Predictors of Belief in Conspiracy Theories.” Journal of Individual Differences 39, no. 4 (2018): 229-237.

Horsley, Richard A. Revolt of the Scribes: Resistance and Apocalyptic Origins. Minneapolis: Fortress, 2010.

Imhoff, Roland, and Pia Karoline Lamberty. "Too Special to be Duped: Need for Uniqueness Motivates Conspiracy Beliefs.” European Journal of Social Psychology 47, no. 6 (2017): 724-734.

Ito, Robert. "Fear Factor: Jack Chick is the World's Most Published Author - And One of the Strangest." Los Angeles Magazine, May 2003.

Jewett, Robert, and John Shelton Lawrence. "Eschatology in Pop Culture.” In The Oxford Handbook of Eschatology, 655-670. Edited by J. L. Walls. Toronto: Oxford University Press, 2008.

Jolley, Daniel, and Karen M. Douglas. "The Effects of Anti-Vaccine Conspiracy Theories on Vaccination Intentions.” Plos ONE 9, no. 2 (2014): e89177. https://doi.org/10.1371/journal.pone.0089177. , and Karen M. Douglas. "The Social Consequences of Conspiracism: Exposure to Conspiracy Theories Decreases Intentions to Engage in Politics and to Reduce One's Carbon Footprint." British Journal of Psychology 105 (2014): 35-36.

Jones, Robert P., Daniel Cox, and Juhem Navarro-Rivera. Believers, Sympathizers and Skeptics: Why Americans are Conflicted about Climate Change, Environmental Policy, and Science. Findings from the PRRI/AAR Religion, Values, and Climate Change Survey. Washington, DC: Public Religion Research Institute, 2014.

Kearns, Laurel. "Cooking the Truth: Faith, Science, the Market and Global Warming." In Ecospirit: Religions and Philosophies for the Earth, 97-124. Edited by L. Kearns and C. Keller. New York: Fordham University Press, 2007.

—. "Green Evangelicals.” In The New Evangelical Social Engagement, 157-178. Edited by B. Steensland and P. Goff. Oxford: Oxford University Press, 2014.

Koester, Craig R. Revelation: A New Translation with Introduction and Commentary. New Haven: Yale University Press, 2014.

Kuersteiner, Kurt. The Unofficial Guide to the Art of Jack T. Chick. Atglen, PA: Schiffer Publishing, 2004.

Leonard L. Thompson, The Book of Revelation: Apocalypse and Empire. New York: Oxford University Press, 1990. 
Lund, Martin. "“[A] Matter of SAVED or LOST': Difference, Salvation, and Subjection in Chick Tracts." In Comics and Power: Representing and Questioning Culture, Subjects, and Communities, 173192. Edited by Rikke Platz Cortsen, Erin La Cour, and Anne Magnussen. Newcastle upon Tyne: Cambridge Scholars Press, 2015.

Martinez, Jessica, and Gregory A. Smith. "How the Faithful Voted: A Preliminary 2016 Analysis." Pew Research Center, November 9, 2016. https://www.pewresearch.org/fact-tank/2016/11/09/how-thefaithful-voted-a-preliminary-2016-analysis/.

Massyngberde Ford, Josephine. Revelation. Garden City, NY: Doubleday, 1975.

McCammack, Brian. "Hot Damned America: Evangelicalism and the Climate Change Policy Debate." American Quarterly 59, no. 3 (2007): 645-668.

Meeks, Wayne A. "Sociological Functions of Apocalyptic Language in Pauline Christianity." In Apocalypticism in the Mediterranean World and the Near East: Proceedings of the International Colloquium on Apocalypticism, Uppsala, August 12-17, 1979, 687-705. Edited by David Helholm. Tübingen: Mohr Siebeck, 1983.

Miller, Shane. "Conspiracy Theories: Public Arguments as Coded Social Critiques: A Rhetorical Analysis of the TWA Flight 800 Conspiracy Theories." Argumentation and Advocacy 39 (Summer 2002): $40-56$.

Misiroglu, Gina, ed. American Countercultures: An Encyclopedia of Nonconformists, Alternative Lifestyles, and Radical Ideas in U.S. History. New York: Routledge, 2009.

Moore, Stephen D. "The Revelation to John." In A Postcolonial Commentary on the New Testament Writings, 436-454. Edited by Fernando F. Segovia and R. S. Sugirtharajah. New York: T \& T Clark, 2007.

Murphy, Frederick J. Apocalypticism in the Bible and Its World: A Comprehensive Introduction. Grand Rapids, MI: Baker Academic, 2012.

Neville-Shephard, Ryan. "Paranoid Style and Subtextual Form in Conspiracy Rhetoric." Southern Communication Journal 83, no. 2 (2018): 119-132.

Nickelsburg, G. W. E. "Social Aspects of Palestinian Jewish Apocalypticism.” In Apocalypticism in the Mediterranean World and the Near East: Proceedings of the International Colloquium on Apocalypticism, Uppsala, August 12-17, 1979, 641-654. Edited by David Helholm. Tübingen: Mohr Siebeck, 1983.

Noll, Mark, and Carolyn Nystrom. "Is the Reformation Over?” Christianity Today, July 1, 2005. https://www.booksandculture.com/articles/2005/julaug/1.10.html. 
Nostradamus. Nostradamus: The Prophecies. A Dual-Language Edition with Parallel Text. Translated by Richard Sieburth. New York: Penguin, 2012.

Oliver, J. E., and T. J. Wood. "Conspiracy Theories and the Paranoid Style(s) of Mass Opinion.” American Journal of Political Science 58, no. 4 (October 2014): 952-966.

Pippin, Tina. "The Revelation to John.” In Searching the Scriptures, vol. 2, 109-130. Edited by Elisabeth Schüssler Fiorenza. New York: Crossroad, 1994.

Portier-Young, Anthea. Apocalypse against Empire: Theologies of Resistance in Early Judaism. Grand Rapids, MI: Eedrmans, 2011.

Roser-Renouf, Connie, Edward Maibach, Anthony Leiserowitz and Seth Rosenthal. "Global Warming, God and the 'End Times.” Yale Program on Climate Change Communication, July 26, 2016.

Rossing, Barbara. "Hastening the Day When the Earth Will Burn: Global Warming, 2 Peter, and the Book of Revelation." In The Bible in the Public Square: Reading the Signs of the Times. Edited by Cynthia Briggs Kittredge, Ellen Bradshaw Aitken and Jonathan A. Draper. Minneapolis: Fortress Press, 2008.

Schaefer, Nancy A. "The Left Behind Series and Its Place Within the American Evangelical Subculture." In End of Days: Essays on the Apocalypse from Antiquity to Modernity, 287-308. Edited by Karolyn Kinae and Michael A. Ryan. Jefferson, NC: McFarland, 2009.

Schulman, Jeremy. "Every Insane Thing Donald Trump Has Said About Global Warming.” Mother Jones, December 12, 2018. https://www.motherjones.com/environment/2016/12/trump-climate-timeline/.

Schüssler Fiorenza, Elisabeth. Revelation: Vision of a Just World. Minneapolis: Fortress Press, 1991.

Schwadel, Philip, and Gregory A. Smith. "Evangelical Approval of Trump Remains High, But Other Religious Groups are Less Supportive.” Pew Research Center, March 18, 2019, https://www.pew research.org/fact-tank/2019/03/18/evangelical-approval-of-trump-remains-high-but-otherreligious-groups-are-less-supportive/.

Scopello, Madeleine. "The Revelation of Adam." In The Nag Hammadi Scriptures, 343-345. Edited by Marvin Meyer. San Francisco: HarperOne, 2007.

Solnit, Rebecca. A Paradise Built in Hell: The Extraordinary Communities That Arise in Disaster. New York: Penguin, 2010.

Stover, Dawn. "Evangelicals for Climate Action.” Bulletin of the Atomic Scientists 75, no. 2 (2019): 6672.

Sunstein, Cass R., and Adrian Vermeule. "Conspiracy Theories: Causes and Cures." Journal of Political 
Philosophy 17, no. 2 (2009): 202-227.

Sutton, Matthew Avery. American Apocalypse: A History of Modern Evangelicalism. Cambridge, MA: Belknap / Harvard University Press, 2014.

Swami, V., and R. Coles. "The Truth is Out There: Belief in Conspiracy Theories." The Psychologist 23 (2010): 560-563.

van Prooijen, Jan-Willem, and Nils B. Jostmann. "Belief in Conspiracy Theories: The Influence of Uncertainty and Perceived Morality.” European Journal of Social Psychology 43 (2013): 109-115.

—. "Sometimes Inclusion Breeds Suspicion: Self-Uncertainty and Belongingness Predict Belief in Conspiracy Theories.” European Journal of Social Psychology 46 (2016): 267-279.

Vanhoye, Albert. "L'Utilisation du livre d'Ézéchiel dans L'Apocalypse.” Biblica 43 (1962): 436-476.

Vox, Lisa. "Why Don't Christian Conservatives Worry about Climate Change? God.” Washington Post, June 2, 2017. https://www.washingtonpost.com/posteverything/wp/2017/06/02/why-dontchristian-conservatives-worry-about-climate-change-god/.

Walls, Jerry L. "Introduction.” In The Oxford Handbook of Eschatology, 3-18. Edited by J. L. Walls. Toronto: Oxford University Press, 2008.

Weber, Timothy P. "Millenialism.” In The Oxford Handbook of Eschatology, 365-384. Edited by J. L. Walls. Toronto: Oxford University Press, 2008.

Weldy, Lance. "Graphically/Ubiquitously Separate: The Sanctified Littering of Jack T. Chick's FundyQueer Comics." In Graphic Novels for Children and Young Adults: A Collection of Critical Essays. Edited by Michelle Ann Abate and Gwen Athene Tarbox. Jackson, MS: University of Mississippi Press, 2017. https://doi.org/10.2307/j.ctv5jxmqd.

Wilkinson, Katharine K. Between God and Green: How Evangelicals Are Cultivating a Middle Ground on Climate Change. Oxford: Oxford University Press, 2012. Zaleha, Bernard Daley, and Andrew Szasz. "Why Conservative Christians Don't Believe in Climate Change." Bulletin of the Atomic Scientists 71, no. 5 (2015): 19-30.

Zaleha, Bernard Daley, and Andrew Szasz. "Why Conservative Christians Don't Believe in Climate Change." Bulletin of the Atomic Scientists 71, no. 5 (2015): 19-30. 